\title{
Title I Schools: The Student-Based Impact Of Online, On-Demand Professional Development On Educators
}

\author{
Steven Shaha, PhD, DBA, University of Utah, USA \\ Kelly Glassett, PhD, University of Utah, USA \\ Aimee Copas, PhD, Brigham Young University, USA \\ Heather Ellsworth, Brigham Young University, USA
}

\begin{abstract}
Title I students remain among the most challenging population for achieving significant gains in academic performance and standardized test scores. This multi-state, quasi-experimental, preversus-post study reflects the comparative Title I gains for math and reading scores for teachers participating in an online, on-demand professional development program school-wide versus nonparticipating Title I in their respective districts as benchmarks. Average Title I gains in reading were $4.8 \%(p<.001)$ versus $0.1 \%$ (ns) in the non-participating Title I schools. For math scores, non-participating Title I schools in the districts saw a decline of $5.9 \%(p<.001)$, while Title I schools participating in the professional development experienced a gain of $7.3 \% \quad(p<.001)$. Conclusions are that significant advantages for Title I students are achieved when teachers participate actively in such a high impact, high accessibility professional development program.
\end{abstract}

Keywords: Title 1; Professional Development; Professional Learning; Improved Student Performance

\section{INTRODUCTION}

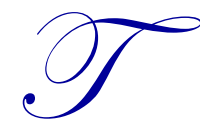

itle 1 schools are described as "low income" and "disadvantaged" schools (Kirby, 2003; U.S. Dept. of Education, 2001). Within them are found a large proportions of students suffering from low achievement, described generally as being unprepared to advance in grade levels (Hung, 2011; Kirby, 2003; U.S. Dept. of Education, 2001). Title I schools have recently been targeted for improvements by mandated interventions that have been shown in research to be highly speculative, minimally effective, and overly restrictive (Waddell 2011). Meeting the imperative for improved accountability toward increasing performance for disadvantaged, Title I students will require programs and interventions beyond those shown to fail in the past, solutions that have been proven through research to achieve beneficial, substantive achievement gains (United States General Accounting Office, 2000).

Despite the emergent need, solutions for increasing achievement among students in Title I schools must represent cost-effective, highly scalable approaches that can reach large numbers of students with high efficacy. To scale in meeting the needs of so many students, best programs, therefore, will need to rely upon training teachers to be more effective, raising their impactfulness and thereby the score for their students. For this reason, there is an ever-increasing imperative to increase the impactfulness of professional development (PD) programs offered to educators, especially those in the role of teacher. Perhaps the only hope of reaching the many students in Title I settings is to first reach their teachers.

Historically, PD programs have relied primarily on seminar-like experiences for teachers (Borko, 2004 ; Clarke \& Hollingsworth, 2002). However, requiring or enabling teachers to spend extensive time away from the classroom is costly to educational systems and disruptive to the norms of day-to-day classroom management. Seminars necessitate replacement teachers at additional expense, and these generally are unacquainted with the 
students or their needs, collectively as classroom group or individually. For these intuitive reasons, therefore, it is increasingly mission-critical that PD programs and offerings be implemented cost-effectively, while still reflecting proven success for helping teachers impact student achievement (c.f. Buczynski and Hansen 2010; Avalos 2011; Garet et al. 2001; Desimone et al. 2002; Shaha et al. 2004; Meiers and Ingvarson 2005; Wasik and Hindman 2011). The driving data should substantiate that this more cost-effective and less disruptive approach is not solely cheaper, but that it results in better impacts for student performance as the highest driving goal.

Online, on-demand programs offer just such an efficient, cost-effective alternative to traditional seminarlike approaches. Such programs enable teachers to attend without compromising their ability to still support their teaching load. Additionally such programs, when well designed and delivered, also enable teachers to participate in modules that either leaders determine are most needed for them collectively or individually, whether aimed as scholastic subjects for improved teaching skills, or other areas for continuous personal improvement. And teachers can be self-guided, of course, and select areas of personal interest or desired personal growth regarding which they desire the greatest instruction.

More importantly, Internet-based, online, on-demand programs have recently been proven effective in rigorous research. One study reflected data from 39 states and quantified comparative gains in standardized assessments performance for schools participating in Internet-based, online, on-demand programs versus their own respective districts as benchmarks (Shaha and Ellsworth, 2013). Results showed significant advantages in both math and reading performance, from $15 \%$ to $18 \%$, for schools whose teachers actively participated in the Internet-based, on-demand PD versus their respective districts, the latter gaining only $2 \%$ to $4 \%$ in the same period. Equally important, those gains achieved were not haphazard, but were sustained into the next year (Shaha, Glassett \& Copas 2015a). Another recent multi-state study showed that successes from the same PD approach resulted in gains still sustained seven years through continued PD participation (Shaha, Glassett \& Copas 2015b).

Those studies reviewed reflect the impacts of this broad accessible, high impact, low cost approach to professional development on schools within a variety of states and socio-economic characteristics (Shaha \& Ellsworth 2014). However, a review of the literature has provided no such research nor proven PD approaches that address the needs of Title I schools and their students (Hung, 2011). Arguably it is Title I settings that most need the additional lift form impactful teacher PD, yet no such data could be found. We determined this to be an unjustifiable travesty, and so undertook the research ourselves (Wolf \& Jacob, 2013).

The research question for the present study focused on whether significant and beneficial impacts for online, on-demand, readily-accessible professional development would have significantly beneficial impacts for students, through their teachers, within Title I schools.

\section{METHODS}

A quasi-experimental study design was undertaken to contrast the teachers in Title I schools (Title I Userschools) participating in an online-delivered professional development (PD) as the "treatment group" with their respective Title I Districts that did not use the professional learning tool as the "control group." Inclusion in the PD participation Title I User-schools was limited to schools with use of the commercially-delivered PD offering (PD $360 \AA$ and Observation $360 \AA$, School Improvement Network, Salt Lake City) at a minimum of 90 percent of teachers at a minimum mean of 90 minutes per teacher (Shaha \& Ellsworth, 2013). The PD offering is best defined as an on-demand, Internet-accessible product suite through which educators can participate in capabilities ranging from viewing instructional videos on teaching techniques, including participation in communities and posting and downloading PD-related materials from other PD users.

Title I User-schools included in the "treatment group" were identified from data automatically captured through use of the Internet-based PD offering, as provided by the PD provider (School Improvement Network), and confirmed as Title I through publically available, Internet accessed data sources. Title I District included in the "control group" were limited to those to which each User-school belonged. All Title I User-schools and Title I Districts then reached final inclusion only when Title I User-schools constituted one-half or fewer of all schools within their Title I District. This final filter ensured that "treatment versus control" would represent socio- 
economically and educator-resource comparable quasi-experimental groups, and no Title I District's quantified performance would represent any overwhelming bias from too large a representation of Title I User-schools.

The final sample included 422 Title I User-schools within 111 Title I Districts, representing 26 of the United States. Student performance data were then added for each Title I User-schools and Title I Districts, gathered from publically available web sources for the two consecutive school years, 2010-2011 and 2011-2012. When not available online, performance data were gathered from district-supplied Excel spreadsheets as requested with Institutional Review Board (IRB) approval where IRB relationships existed. Performance data analyzed were defined as the sum of the percentages of students rated either proficient or advanced, for math and reading, reflecting whatever standardized test was in use, thus performance data were normalized for differences between assessment tools by setting (Shaha \& Ellsworth 2013). All analyses were conducted using SPSS version 17.0 or higher (PASW Statistics, SPSS, 2009, with SAS used for confirmatory purposes when results were close to $\mathrm{p}<0.05$ ).

\section{RESULTS}

Student performance levels showed consistent and statistically significant advantages favoring Title I Userschools with the professional learning tools versus their respective and otherwise-equal Title I Districts. Title I User-schools whose teachers participated in PD significantly outperformed their respective districts in student performance in both reading and mathematics. Moreover, improvements observed in Title I Districts implied that gains made were likely boosted for each entire district as a reflection of Title I User-schools gains nested within the district-comprehensive averages.

\section{Reading}

Title I User-schools demonstrated statistically significant year-over-year increases in reading as reflecting in the combined percent of students categorized as proficient and advanced on annual standardized tests. While minimal mean gains of $0.1 \%$ were experienced across districts, the Title I User-schools gained an average of $4.8 \%$ year-over-year, a performance advantage $4.6 \%$ better $(\mathrm{p}<.001)$ (see figures 1 and 2$)$. Further, the second year data indicated that PC participation for Title I User-schools was correlated with a newly evidenced performance gap where none existed prior to the PD use. 
Figure 1. Comparative change in reading performance

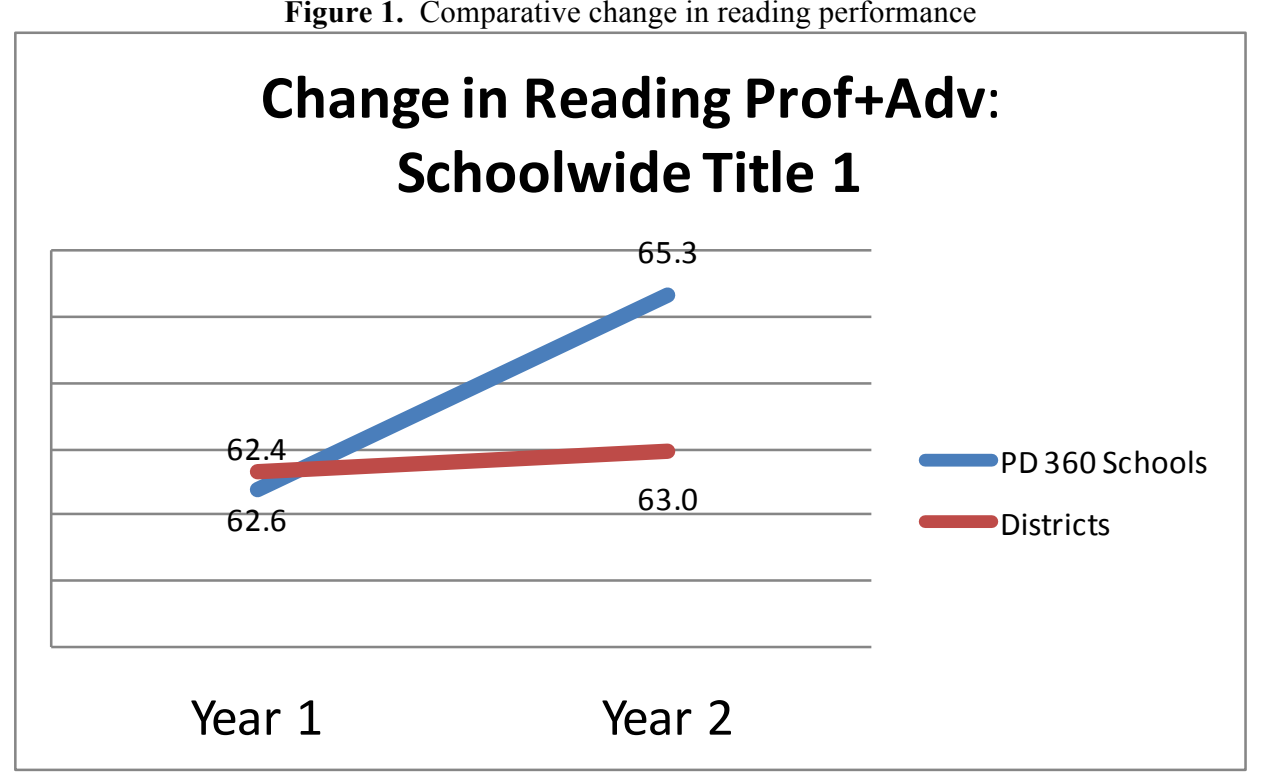

Figure 2. Percent change in reading performance

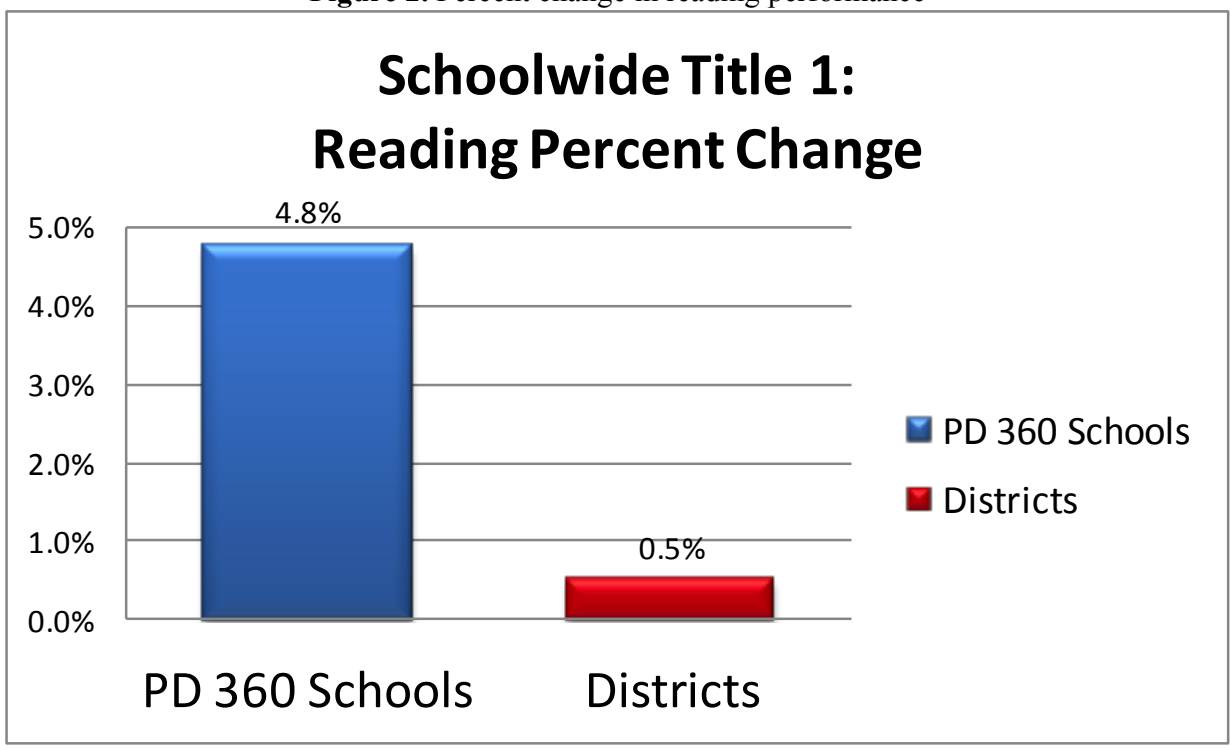

\section{Mathematics}

As with reading, the Title I User-schools experienced significant greater gains in mathematic proficiency above those experienced by their matched Title I Districts collectively $(\mathrm{p}<.001)$. Unlike with Reading, results in mathematics showed that the districts cumulatively saw a decline of $5.9 \%$ of students scoring proficient or advanced, while the participating Title I User-schools within those same districts experienced a gain of $7.3 \%$ for the same time period. The year-over-year growth advantage was $13.2 \%(\mathrm{p}<.001)$ favoring of the Title I User-schools (see figure 3 and 4). Thus even the improvements experienced in Title I User-schools was insufficient to raise performance for the Title I Districts within which they were imbedded. 
Figure 3. Comparative gains in math performance

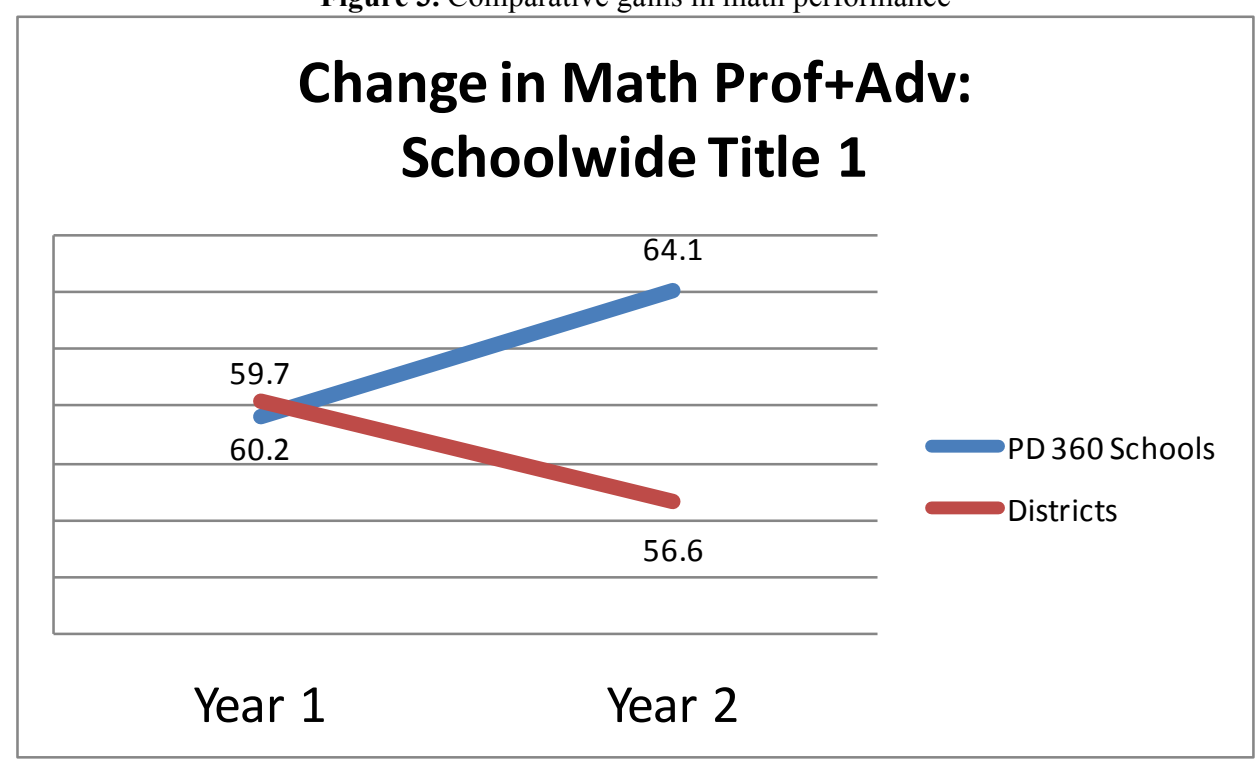

Figure 4. Percent change in math performance

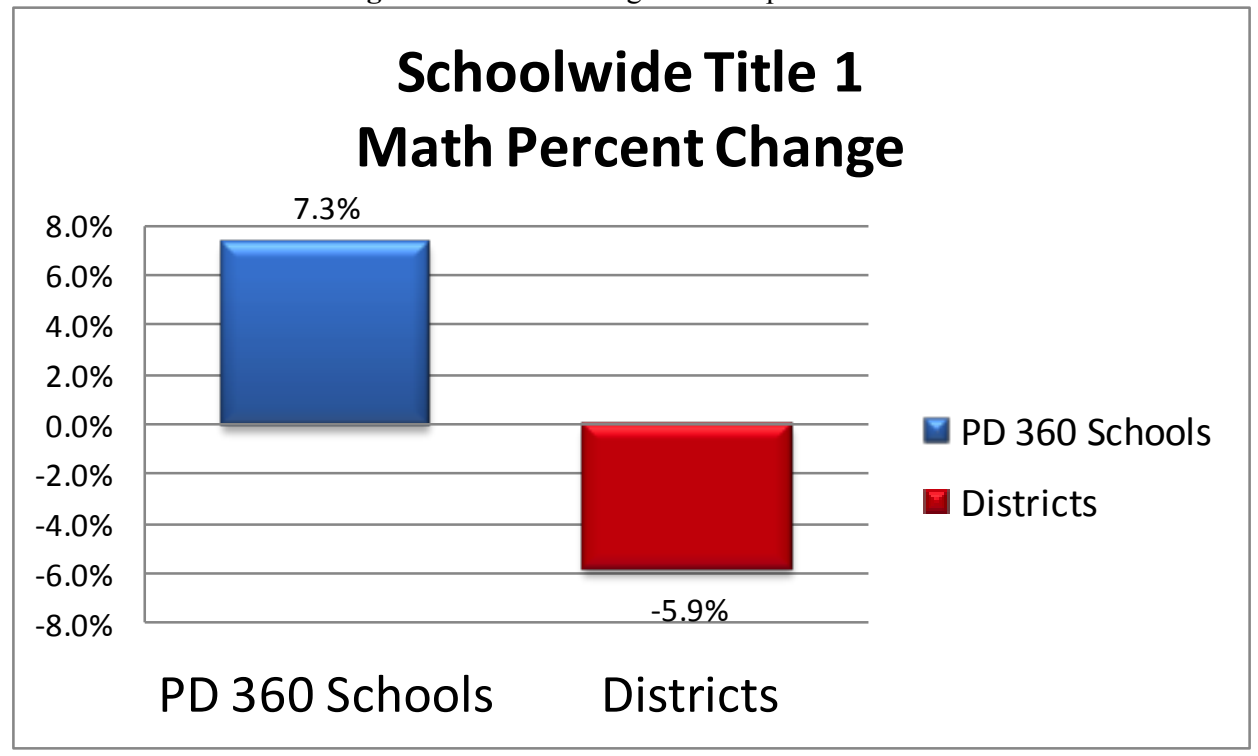

CONCLUSION

To our knowledge, no multi-state, large sample study has successfully documented significant advantages in teacher professional development for Title I schools. In this unique, multi-state study, students of teachers in Title I schools that participated in the online, on-demand, Internet-delivered professional development studied experienced significantly higher end scores and year-to-year growth than did their peers within the same districts whose schools did not have teacher participation. The advantage of participation was verified for both reading performance and mathematics performance in terms of significantly better end states and year-to-year increases in the proportion of students classified as proficient or advanced on standardized tests. The pattern documented reflected the mean performance levels for over 200 participating schools collectively versus their 111 districts within 26 states. 
The goal of educators and educational institutions, particularly Title I schools, is to lift students to their highest possible levels of academic accomplishment. Historically, gaining significant score growth within Title I schools has been challenging, even when efforts were focused on populations within single schools, or single districts, or single states. To have documented such significant impact across such a large and comprehensive sample is not only noteworthy, but substantive enough to merit attention at policy-making levels. These data show that teachers, when provided with substantive and readily-accessible materials for enhancing their skills and capabilities, apparently have greater and more substantive impact on their students.

Title I students have been justifiably categorized as "disadvantaged" for a list of reasons. However, these data raise the question whether advantages can be achieved for these students when teachers are equipped with sztate-of-the-art Internet-delivered professional development. While contrasts of impacts versus non-Title I schools and students was not included in this study, previous research has left little doubt that these gains were both predictable, and likely equal to or greater than those found within non-Title I settings.

These data leave little argument that online, on-demand professional development merits broader utilization and evaluation throughout the variety of school settings within which teacher continue to effort selflessly to help their students grow and maximize their potentials. These findings establish a data-driven recommendation that this approach is worthy of strong consideration. The focus on educational settings focused on meeting the needs of "disadvantaged" students, as reflected in this study, is both timely and appropriate, and the findings leave little doubt regarding this student-focused investment. Whether other PD approaches might have achieved similar or equal results remains untested and, from the literature, doubtful.

\section{AUTHOR INFORMATION}

Dr. Kelly Glassett has nearly thirty years' experience in the classroom and in educational research. He has presented and published extensively. With over forty professional presentations and peer-reviewed publications, with a particular emphasis on teacher education, technology, reading, and assessment. He remains cutting-edge in emerging educational research, as he serves on the editorial review boards of publications such as Action in Teacher Education, The Reading Teacher, Journal of Research on Technology in Education, and Journal of Educational Computing Research. Dr. Glassett holds a BA in English; Spanish, and Special Education licensures; a MEd in Education; and $\mathrm{PhD}$ in Teaching and Learning.

Professor Shaha has $35+$ years' in program evaluation and outcomes research with $100+$ educational program evaluations within $200+$ organizations and governments in 11 countries, four continents, public, private, for-profit and not-for-profit. Steve holds MA, MEd and PhD in Research Methods \& Applied Statistics and Business Administration (DBA). He has $220+$ presentations, $100+$ journal publications, three books. He lectured at $18+$ universities, including Harvard, Cambridge (UK), Columbia, Cornell, UCLA and Zayed University (UAE). He presented twice to the United Nations in 2015. Consults for 50+ non-educational organizations include Disney, Ritz-Carlton, RAND, Coca-Cola, Time-Warner, NewLine Cinema, and 200+ healthcare-focused organizations.

Aimee Copas is the Executive Director for the ND Council of Educational Leaders; the organization that provides the strongest unifying voice representing/supporting educational leaders in pursuit of quality education for all students. Aimee is also an adjunct professor for the University of Mary and NDSU. Aimee was the Associate Vice Chancellor for Academic Affairs/Director of Research for the North Dakota University System, a college dean, principal, English teacher, basketball coach, \& National Trainer for a pharmaceutical company. Aimee acquired her undergraduate degree from the University of Mary, her MS at Northern State University, \& Doctorate from the University of South Dakota.

Heather Ellsworth recently graduated from Brigham Young University with a Bachelor degree in Applied Statistics. In current years, she has received several awards for her service in the community and participates in a local orchestral organization. Most of her academic research includes student performance in schools and finding improvements for teachers. She currently works as a Project Analyst for a company in Scottsdale Arizona and hopes to continue her education through a Master's degree. 


\section{REFERENCES}

A snapshot of title I schools, 2000-01 (2003). In United States. Department of Education. Policy and Program Studies Service., Sheila Nataraj Kirby ... [et. al.]. (Eds.), Washington, D.C.: U.S. Dept. of Education, Office of the Under Secretary, Policy and Program Studies Service.

Avalos, B. (2011). Teacher professional development in teaching and teacher education over ten years. Teaching and Teacher Education, 27(1), 10-20. doi:10.1016/j.tate.2010.08.007.

Borko, H. (2004). Professional development and teacher learning: Mapping the terrain. Educational researcher, $33(8), 3-15$.

Buczynski, S., \& Hansen, C. B. (2010). Impact of professional development on teacher practice: Uncovering connections. Teaching and Teacher Education, 26(3), 599-607. doi:10.1016/j.tate.2009.09.006.

Clarke, D., \& Hollingsworth, H. (2002). Elaborating a model of teacher professional growth. Teaching and teacher education, 18(8), 947-967.

Darling-Hammond, L. (2004). Standards, accountability, and school reform. Teachers College Record, 106(6), 1047-1085.

Desimone, L. M., Porter, A. C., Garet, M. S., Yoon, K. S., \& Birman, B. F. (2002). Effects of professional development on teacher's instruction: Results from a three-year longitudinal study. Educational Evaluation and Policy Analysis, 24(2), 81-112.

Farnsworth, B., Shaha, S., Bahr, D., Lewis, V.. \& Benson. L. (2002). Preparing tomorrow's teachers to use technology: Learning and attitudinal impacts on elementary students. Journal of Instructional Psychology, 29(3).

Garet, M. S., Porter, A. C., Desimone, L., Birman, B. F., \& Yoon, K. S. (2001). What makes professional development effective? Results from a national sample of teachers. American Educational Research Journal, 38(4), 915.

Hung, C. Y. (2011). The study on the causes of the underprivileged students' low achievement.

King, K. P. (2002). Identifying success in online teacher education and professional development. The Internet and Higher Education, 5(3), 231-246. doi:10.1016/S1096-7516(02)00104-5

Kirby, S. N., McCombs, J. S., Naftel, S., \& Murray, S. E. (2003). A Snapshot of Title I Schools, 2000-01.

Knight, P. (1998). "Professional Obsolescence and Continuing Professional Development in Higher Education." Innovations in Education \& Training International, Volume 35, Issue 3, September 1998, pages 248-256.

Magidin, d. K., Masters, J., O'Dwyer, L. M., Dash, S., \& Russell, M. (2012). Relationship of online teacher professional development to seventh-grade teachers' and students' knowledge and practices in English language arts. The Teacher Educator, 47(3), 236-259. doi:10.1080/08878730.2012.685795

Masters, J., Kramer, R. M. d., O'Dwyer, L., Dash, S., \& Russell, M. (2012). The effects of online teacher professional development on fourth grade students' knowledge and practices in English language arts. Journal of Technology and Teacher Education, 20(1), 21-46.

Meiers, M., \& Ingvarson, L. (2005). Investigating the links between teacher professional development and student learning outcomes. Australian Council for Educational Research, 1, 1-93.

Rienties, B., Brouwer, N., \& Lygo-Baker, S. (2013). The effects of online professional development on higher education teachers' beliefs and intentions towards learning facilitation and technology. Teaching and Teacher Education, 29(0), 122-131. doi:10.1016/j.tate.2012.09.002

Santagata, R. (2009). Designing video-based professional development for mathematics teachers in low-performing schools. Journal of Teacher Education, 60(1), 38-51.

Sebastian, J., \& Allensworth, E. (2012). The influence of principal leadership on classroom instruction and student learning: A study of mediated pathways to learning. University Council for Educational Administration, 10, 626-663.

Shaha SH, Ellsworth H (2013). Quasi-experimental Study of the Impact of On-demand Professional Development on Students Performance. International Journal of Evaluation and Research in Education (IJERE). Vol.2, No. 4.

Shaha SH, Ellsworth H (2014). Predictors of Success for Professional Development: Linking Student Achievement to School and Educator Successes through On-Demand, Online Professional Learning. Journal of Instructional Psychology (JIP), Vol. 40, No. 1.

Shaha, Glassett \& Copas (2015a). Sustaining Student Gains From Online On-Demand Professional Development. Journal of International Education Research. Vol 11, No. 3. 
Shaha SH, Glassett K, Ellsworth H (2015b). Long-term Impact of On-demand Professional Development on Student Performance: A Longitudinal Multi-State Study. Journal of International Education Research. Vol 11(1).

Shaha, S. H., Lewis, V. K., O'Donnell, T. J., \& Brown, D. H. (2004). Evaluating professional development: An approach in verifying program impact on teachers and students. Journal of Research in Professional Learning, 1(1), 1 .

United States. General Accounting Office. (2000). In United States General Accounting Office. (Ed.), Title I program : Stronger accountability needed for performance of disadvantaged students : Report to congressional requesters Washington, D.C. P.O. Box 37050, Washington 20013: U.S. General Accounting Office.

Waddell, C. (2011, School improvement grants: Ransoming title I schools in distress. Current Issues in Education,

Wasik, B. A., \& Hindman, A. H. (2011) Improving Vocabulary and Pre-Literacy Skills of at-Risk Preschoolers through Teacher Professional Development. Journal of Educational Psychology 103(2), 455-69.

Wilson, S., \& Berne, J. (1999, Teacher learning and the acquisition of professional knowledge: An examination of research on contemporary professional development. Review of Research in Education, 24 1999, 24, 173 209.

Wolf, P. J., \& Jacob, A. M. (2013). School choice. The Economics of Inequality, Poverty, and Discrimination in the 21st Century, 398-414. 